\title{
From the best results of medical research to therapy involving the context of an individual patient
}

\author{
Od najlepszych wyników medycznych badań naukowych do terapii \\ uwzględniającej kontekst indywidualnego pacjenta
}

\author{
Małgorzata K. Szerla ${ }^{1,2}$, Dorota E. Ortenburger ${ }^{3,4}$ \\ 'Department of Anaesthesiology and Intensive Care, The Provincial Specialist Children’s Hospital, Kielce, Poland \\ Head of the Department: Małgorzata Szerla MD, PhD \\ 2Department of Emergency Medicine, Institute of Public Health, Faculty of Health Sciences, Jan Kochanowski University, Kielce, Poland \\ Head of the Department: Prof. Siarhei Panko MD, PhD \\ ${ }^{3}$ Departament of Physiotherapy, Institute of Physical Education, Tourism and Physioterapy, The Faculty of Pedagogy, \\ Jan Długosz University, Czestochowa, Poland \\ Head of the Department: Assoc. Prof. Jacek Wąsik PhD \\ ${ }^{4}$ The Pain Treatment Centre, City Policlinic Hospital, Czestochowa, Poland \\ Head of the Centre: Wojciech Konieczny MD
}

Key words: best results, contextualisation, individual therapy.

Słowa kluczowe: najlepsze wyniki badań, kontekstualizacja, indywidualna terapia.

\begin{abstract}
Contextualisation is the process of identifying specific factors of a patient's life situation, which is focused on individualised care. In the light of reference books, contextualisation is an integral part of therapy with an active participation of the patient and/or his/her carers. Among many factors that constitute the functioning of a person, family and socio-material situation, access to professional health care, and the ability to exercise self-care are major contextual factors of the patient's health situation. The purpose of this article is to draw attention to the fact that the limiting oneself exclusively to algorithms as procedures based on the best evidence (best evidence medical research - BEMR) may raise the specific danger of underestimating the variability of individual responses of the human body under the influence of factors forming a personal context. The phenomenon of contextualisation in the treatment of an individual patient is still not adequately disseminated, although it is an important element in the decision-making process, with proven impact on the efficiency and quality of care and satisfaction of a patient.
\end{abstract}

\section{Streszczenie}

Kontekstualizacja to proces identyfikowania specyficznych czynników sytuacji życiowej konkretnego pacjenta, ukierunkowany na zindywidualizowanie opieki medycznej. W świetle literatury przedmiotu kontekstualizacja stanowi integralną część terapii z aktywnym udziałem pacjenta i/lub jego opiekunów. Wśród wielu czynników składających się na całość funkcjonowania danej osoby sytuacja rodzinna, społeczno-materialna, dostęp do profesjonalnej opieki zdrowotnej, a także możliwości sprawowania samoopieki stanowią główne czynniki kontekstowe sytuacji zdrowotnej pacjenta. Celem artykułu jest zwrócenie uwagi na fakt, że ograniczanie się jedynie do algorytmów jako procedur opartych na najlepszych dowodach (best evidence medical research - BEMR) może rodzić konkretne niebezpieczeństwo niedoszacowania zmienności indywidualnej odpowiedzi organizmu człowieka pod wpływem czynników tworzących osobisty kontekst. Uwzględnianie fenomenu kontekstualizacji w terapii indywidualnego pacjenta wciąż jeszcze nie jest należycie rozpowszechnione, mimo że stanowi ważny element w procesie podejmowania decyzji o udowodnionym wpływie na skuteczność i jakość terapii oraz satysfakcję pacjenta.

\section{Introduction}

The basic tasks of medicine are [1] to diagnose and [2] to propose treatment. Making clinical decisions by a doctor about a patient should be based on receiving a reply to the question: "What kind of treatment and care is best for the patient at the present moment?"
Undoubtedly, the implementation of the chosen therapy should be adapted to the individual situation of the patient so that this selected treatment procedure is effective and safe [1]. However, a seemingly simple formal factor such as lack of a patient's confidence in a doctor can be a serious impediment to the realisa- 
tion of this task. Additionally, in such a situation, a doctor's confidence in a patient also becomes limited and much disturbed. It would seem that the optimal solution to such a serious problem is to propose to a patient therapy based on "the best evidence" of evidence-based medicine (EBM).

Over the years, in literature on medical research, emphasis has been put on using mainly quantitative verification methods. Therefore, a quantitative approach to evaluation of the effects of certain types of treatment and care gradually entered and anchored in medical practice and in other scientific disciplines dealing with human functioning [2]. In medical practice it quickly transpired that the enthusiasm for EBM understood in such a way obscured the fundamental process of identifying factors specific to the individual circumstances of a patient.

It should be noted that in 1996 Sackett et al. defined evidence-based medicine as a conscientious and reasonable use of current best evidence in making decisions about the care of an individual patient. Those authors also emphasised that such an approach requires from the doctors examination of the clinical indicators that result from contextual factors, i.e. preferences and a patient's situation and considering them in the care plan accordingly. But even at that point it could be noticed that doctors pursued their goals and took shortcuts, ignoring individual spheres of their patients' lives [3]. However, in the pursuit of statistical significance, personal aspects of patients' lives, which always affect their well-being, as well as the course of the disease and treatment, cannot be neglected. All psycho-social-environmental factors in the context of the patient should be understood and considered because they affect the quality of treatment and care. The factors include family situation, social and material status, access to widely-defined care, as well as individual skills and capabilities of patient care [4].

The right approach of a doctor and/or a therapist to a person poorly controlling his or her disease may result in the more conscious and responsible engagement of a patient in the process of their own treatment. Motivating a patient to self-discipline in regular taking of medicine (e.g. anti-asthmatic, antihypertensive) or in following a diet results in the improvement of treatment outcome and in satisfaction of a patient $[5,6]$.

\section{The best results of medical research versus decision-making error}

According to The Institute of Medicine, an independent institution acting on a non-profit basis, evidencebased practice is an integration of the best research results, clinical experience of the therapist and a patient's values [7]. However, having current knowledge and the ability to apply it in therapeutic practice does not eliminate wrong decisions while choosing the treatment and care for an individual patient. Many authors, publishing in recent years in their scientific articles, have been using the term "contextual error" to describe a certain type of erroneous medical judgment. This error is understood as the result of not considering the information specific to an individual patient $[8,9]$. Therefore, problems with the proper implementation of treatment and care may arise due to paying insufficient attention to the situational context of the patient $[1,10]$.

Decision-making errors may occur whenever a physician, a psychologist, or another therapist does not identify vital information or improperly incorporates it in the clinical procedure. Contextual error in planning appropriate treatment and care occurs when elements such as the environment and attitude of the patient are not considered. All other errors in decision-making are classified as the so-called biomedical errors [10]. In contrast to biomedical errors that are not specific with regard to an individual person, not knowing the patient context is an obstacle to individualising patient care [11]. Breslin et al. relate the concept of contextualisation to avoiding contextual errors by obtaining and taking into account relevant information concerning the patient's situation, preferences, and wishes [12]. Stange clearly defines contextualisation as the personalised use of the best scientific evidence (available from EBM), harmonised by the best data obtained from the patient's personal context [13]. Kim et al. made a postulate to conduct individualisation of clinical decisions based on the contextual knowledge of the beliefs and values recognised by the patient as well as his/her responsibilities at work, at home and/or at school. The authors emphasise that this is of particular importance for certain groups of high-risk patients, such as people with addiction problems [14]. There are methods to assess a doctors' propensity for making contextual and biomedical errors in clinical encounters with the so-called standard patient [15].

The results of a study conducted among the physicians published by Weiner revealed a high level of decision-making errors in clinical situations that required paying particular attention to the context of a patient. In that study, the physicians had to deal with unexpected visits of patients who presented simple outpatient complaints. The doctors used norms of the algorithmic approach to patient care for such patients. With respect to $73 \%$ of those patients, the doctors took the right decisions. However, the percentage of correct decisions decreased to $22 \%$ when contextual factors complicating the patient's image were introduced. Those factors required the creation of alternative patient care plans [11]. Over the last 20 years contextual errors in the interpretation and application of EBM have been observed. This phenomenon can be explained in several ways. Contextual issues, including low health awareness of patients and their 
families, lack of means to pay for medicines, a sense of responsibility of a carer, improper diet and malnutrition of patients, are well documented. Many patients are affected by these problems, which have a direct influence on the effects of treatment $[11,16]$.

Determining important details of the patient's life has always been clinically significant. Identifying the patient's cognitive skills, his/her emotional state, cultural and spiritual beliefs, attitude towards the disease and health care system, access to social services, family and environmental support, as well as fulfilment of the duty of care by his/her family and by medical and social care institutions should not be underestimated [1].

\section{Is there a universal way of dealing with each individual patient?}

Medical practice, similarly to psychological practice, involves many types of therapeutic interventions in a variety of situations involving a variety of patients.

The main difficulty is the fact that although the contextual reasoning is essential for the generation and organisation of new knowledge, it cannot be described solely by using the language of quantitative methods. Also, the tools for analytical thinking about care individualisation should be looked for elsewhere.

Qualitative research begins with the collection of data, so that the person examined can express himself or herself, e.g. how they see and feel about their situation. This way one can discover the meaning of the patient's manifested behaviour, constructed by him/ her within a certain context of desires, preferences, behaviours, and their individual situation. The most tangible difference between quantitative and qualitative research lies in the type of raw data collected by the researcher. Data obtained from qualitative research are in the form of text.

In quantitative research the data are in the form of numbers. The meaning of these numbers comes from the tool that was used in the measurement. Hence the difference in the method of analysis of quantitative data obtained from measurements of a set of numbers that are analysed by means of mathematical statistical methods.

Sets of texts require a different approach because the meaning of the text comes from the situation in which the text was produced and recorded. The contextual data can be considered as quality data if there is no ready classification scheme of the cases. In the quantitative study the context is a hindrance, so the point is to neutralise it.

In the qualitative study the researcher does not reject the theory. He/she simply does not let the theory distance him/her from the studied object by forcing him/her to respond with only "yes" or "no" to specific questions. A patient is not one of the cases that has to confirm some kind of order outside him/her. On the contrary; the order is in the patient him/herself and it is waiting to be discovered [17].

\section{The best results of medical research versus contextualisation}

Clinical decision-making involves a quantitative and qualitative approach to data acquisition, i.e. to the first stage of data processing. This stage consists of preparing the data for further "treatment" or interpretation. A clinical approach to the implementation of therapy and patient care is still widely used. This approach involves labelling (pre-diagnosing) signs and symptoms in the patient, their categorisation, and then linking the initial diagnosis (label) with the best evidence of EBM such as recommendations, management, and standards. Unfortunately, all too often clinical reasoning stops at this stage. However, taking into account the patient context requires going beyond the categorisation of running processes and the disorders resulting from them. Moving away from deductive determination of whether a patient fits in the preconceived sets of criteria (algorithms) requires the discovery and exploration of unique elements of a patient's life. Contextualisation should be regarded as a qualitative element in clinical decisionmaking. It is a process of identifying factors specific to the patient's life situation and adapting patient care to this situation. Thus, contextualisation is within the scope of "clinical expertise". The broad concept of "evidence-based decision" includes the skills needed by therapists (providers of therapeutic procedures) for the integration of a clinical condition and the circumstances in which a patient currently finds him/herself (and the preferences resulting from this condition) and scientific research [18].

Contextualisation is also part of the decision-making process assisted by a patient. It allows a patient to identify and predict the implications of proposed interventions that relate to the patient's exceptional circumstances. Considering the patient context aims at selecting and managing the therapeutic strategy that serves the patient's best interests [19]. Related sciences such as anthropology, psychology, and sociology come to aid. We can assume that, similarly to an anthropologist immersed in the study of a particular community, a doctor in a relationship with a patient may be considered a participant in the study. Qualitative methods prevalent in the study of social sciences include concepts that do not compete with quantitative methods (still dominant in medical science), but rather clarify and review them through a systematic qualitative analysis.

The results of qualitative and quantitative analysis should be treated as complementary sources of information. They constitute an integral source of substantive knowledge serving as a tool when making decisions about the choice of treatment and care of a patient. 


\section{The best results of medical research versus doctor-patient communication}

In contrast to quantitative data that can be processed by computers or laboratory equipment, qualitative data must be processed by a human, who always introduces subjective elements. Therefore, contextualisation of medical decisions requires a sense of self-awareness that allows one to sense and separate components of one's own influence exerted on others. The doctor caring for the patient should be aware that, like any other person, he/she has a tendency to have a judgmental reaction to patients. However, if he/ she tames his/her tendency to judge, he/she is able to adopt an open attitude to unveil the patient's situation, views, and preferences. The status of the patient's intellectual competence and his/her natural subjectivity may cause the transmitted data to be of poor quality: chaotic, incomplete, divergent, and consciously or subconsciously manipulated. These data can include overtones and gaps filled in by the assumptions and prejudices raised by the patient in relation to the doctor. If in such cases the critical features of the context of the patient's life situation are not recognised and resolved, taking care of him/her can become dangerous.

In the modern world, mass culture exerts even greater influence on shaping people's attitudes towards health. Communication techniques are characterised by a high degree of standardisation in the transmission of content.

At the same time, direct contact between the creators (press, radio, television, Internet) and recipients of certain information becomes significantly limited and often excluded. Lack of direct communication between a recipient and a creator of information threatens to distort or even to completely misrepresent its original content. The Internet opens virtual channels of interactive communication that penetrate the subconscious, sometimes blurring the differences between the recipient's reality and imagination. The blurring of boundaries between individual and global dimensions of the reality influences the shaping of attitudes and relations with other people. It also applies to the patient-doctor relationship. In addition, reducing the contact time of the doctor and the patient does not only concern critical emergencies. The average time scheduled for a patient is usually too short, which limits the possibility of such clinical decision-making that would take into account the patient context.

The very concept of a patient is very broad as it relates to any person (from a newborn to an elderly person) and sometimes even to a few people at a time (for example a married couple or a mother with a child), who require and await help in a wide range of health needs.

The professions of doctor and of psychologist, by nature, involve access to intimate information and even to secrets concerning the privacy of an ailing person. Direct contact with values recognised by humans as primary values (dignity, freedom, health, and life) binds a doctor to use professional knowledge, skills, and experience for the sake of doing good in return for the confidence the patient grants him. It requires adding a humanitarian dimension to interpersonal relations. In the circumstances set by a disease, which are always difficult for both parties, i.e. a patient and a doctor, it is desirable to create an atmosphere of mutual trust. These relationships are at the personality level, acting simultaneously in two directions: doctor-patient and patient-doctor, since each individual is unique in their physical, mental, and spiritual structure. It is expressed through personality, defined as an individual constellation of personality traits - characteristic and relatively stable properties that are specific to a person. Establishing communication between a doctor and a patient takes place in a natural way through an individual personality structure [20-22]. It should be borne in mind that each party in the patient-doctor relationship strives to preserve their own autonomy and self-esteem.

\section{Summary}

The use of evidence that is only structured and verified by mathematical means is insufficient in the treatment of patients. It can also lead to errors in the structuring of guidelines and standards [23, 24]. Ethical choices that constitute a specific estimation of expected health benefits and potential risk arising from the use of a particular therapy are an inherent element in medical practice in relation to the patient. The goal of treatment is to preserve the principle of proportionality between the risk associated with the use of a particular method of treatment and the achievement of the objective, which is the wellbeing of the patient. This valuation provides a basis for taking personal responsibility by both parties (a doctor and a patient) for the emerging dilemmas, and taking decisions related to them [25]. That is why it is a mistake to strictly implement EBM guidelines as absolute standards in the treatment and care of the patient. This knowledge should rather be linked with skilfully following the possibilities and priorities of an individual patient resulting from his/her context.

Broadly defined individualised care of a patient, in addition to the knowledge of the patient's individual needs and personal preferences, requires a multidisciplinary approach. Very often the involvement of a psychologist, social worker, or hospital chaplain allows the doctor to avoid an erroneous approach to the care and treatment of the patient. Currently, in the evaluation of the efficiency and effectiveness of broadly defined health care, contextual error is not generally taken into account [6]. Expanding assessment of health care performance by considering the patient's context is still an urgent need that requires 
not only the involvement of a doctor and a patient, but also the creation of a system strategy at the level of respective institutions.

Accurate description of causes of failure in diagnosing, treating, and planning care of an individual patient requires considering information "specific" for a patient and skilful linking of them to "the best evidence" gained from population studies. In order for care to be effective, everyone exercising care must take into account the individual factors and conditions of the patient. Individualised patient-oriented care still remains a challenge.

Therefore, researchers and practitioners should join forces to cooperatively apply the study results in clinical practice.

At the same time, the principle should be applied such that innovations developed in a certain field as well as practices already commonly used are subject to critical verification - through rigorous evaluation and considering barriers of the possibility of their use in an individual patient.

It is also important not to assume that "all those other" methods, which have not yet been verified in controlled studies and which are based on the basics of medical sciences in conjunction with the clinical experience of a therapist (doctor, psychologist) and take into account the patient context, are ineffective.

\section{References}

1. Weiner SJ. Contextualizing medical decisions to individualize care: lessons from the qualitative sciences. J Gen Intern Med 2004; 19: 281-5.

2. Schatz E, Schatz IJ. Medicine and political science: parallel lessons in methodological excess. PS: Political Science \& Politics 2003; 36: 417-22.

3. Sackett DL, Rosenberg WM, Gray JA, et al. Evidence based medicine: what it is and what it isn't [Editorial]. BMJ 1996; 312: 71-2.

4. Weiner SJ. From research evidence to context: the challenge of individualizing care [Editorial]. ACP J Club 2004; 141: A11-2.

5. Kohn LT, Corrigan JM, Donaldson MS (eds.) To err is human: building a safer health system. DC: National Academies Pr; Washington, 2000.

6. Weiner SJ, Schwartz A, Weaver F, et al. Contextual errors and failures in individualizing patient care. A multicenter study. Ann Intern Med 2010; 153: 69-75.

7. Institute of Medicine. Crossing the quality chasm: a new health system for the 21st century. DC: National Academy Press. Washington 2001.

8. Falzer PR, Garman MD. A conditional model of evidencebased decision making. J Eval Clin Pract 2009; 15: 1142-51.

9. Falzer PR, Garman DM. Contextual decision making and the implementation of clinical guidelines: an example from mental health. Acad Med 2010; 85: 548-55.

10. Weiner SJ. Contextual error. In: Encyclopedia of medical decision making. Kattan M (ed.). Sage, London 2008; 198-202.

11. Weiner SJ, Schwartz A, Weaver F, et al. Contextual errors and failures in individualizing patient care. A multicenter study. Ann Intern Med 2010; 153: 69-75.
12. Breslin M, Mullan RJ, Montori VM. The design of a decision aid about diabetes medications for use during the consultation with patients with type 2 diabetes. Patient Educ Couns 2008; 73: 465-72.

13.Stange KC. A science of connectedness [Editorial]. Ann Fam Med 2009; 7: 387-95.

14. Kim TW, Samet JH, Cheng DM, et al. Primary care quality and addiction severity: a prospective cohort study. Health Serv Res 2007; 42: 755-72.

15. Weiner SJ, Schwartz A, Yudkowsky R, et al. Evaluating physician performance at individualizing care: a pilot study tracking contextual errors in medical decision making. Med Decis Making 2007; 27: 726-34.

16. Paasche-Orlow MK, Parker RM, Gazmararian JA, et al. The prevalence of limited health literacy. J Gen Intern Med 2005; 20 : 175-84.

17. Konarzewski K. Jak uprawiać badania oświatowe. Metodologia praktyczna. WSiP, Warszawa 2000; 25-40.

18. Haynes RB, Devereaux PJ, Guyatt GH. Clinical expertise in the era of evidence-based medicine and patient choice. Evid Based Med 2002; 7: 36-8.

19. Guyatt G, Montori V, Devereaux PJ, et al. Patients at the center: in our practice, and in our lives. Evid Based Med 2004; 9: 6-7.

20. Kosztołowicz M, Szerla M, Domański M. Propozycja konstrukcji języka komunikacji lekarz-pacjent z uwzględnieniem bólu i osobowości pacjenta. In: Ból i cierpienie. Makiełło-Jarży G, Gajda Z (eds.). Krakowskie Towarzystwo Edukacyjne - Oficyna Wydawnicza AFM, Krakow 2008; 113-34

21.Szerla M, Ortenburger D, Domański M, Tarnopolski A. Selected factors influencing the relationship between the physician and the patient with chronic pain. In: The multidisciplinary approach to health and desease. Selected papers. Janowski K, Steuden S (eds.). CPP Scientific Press, Lublin 2011; 140-8.

22.Szerla M, Kosztołowicz M. Aplikacja wspólnego sensu w wykrywaniu osobowościowego aspektu bólu. In: Ból i cierpienie. Makiełło-Jarży G, Gajda Z (eds.). Krakowskie Towarzystwo Edukacyjne - Oficyna Wydawnicza AFM, Kraków 2009; 17-9.

23. Falzer PR, Garman DM. Contextual decision making and the implementation of clinical guidelines: an example from mental health. Acad Med 2010; 85: 548-55

24. Falzer PR, Garman MD. A conditional model of evidencebased decision making. J Eval Clin Pract 2009; 15: 1142-51.

25.Jan Paweł II, Fides et ratio. Wydawnictwo Diecezji Tarnowskiej Byblos, Tarnów 1998.

\section{Address for correspondence:}

\section{Małgorzata Szerla MD, PhD}

Department of Emergency Medicine

Faculty of Health Sciences

Jan Kochanowski University

al. IX Wieków Kielc 19, 25-317 Kielce, Poland

Phone: +48 60339839

E-mail: szerla@wp.pl 